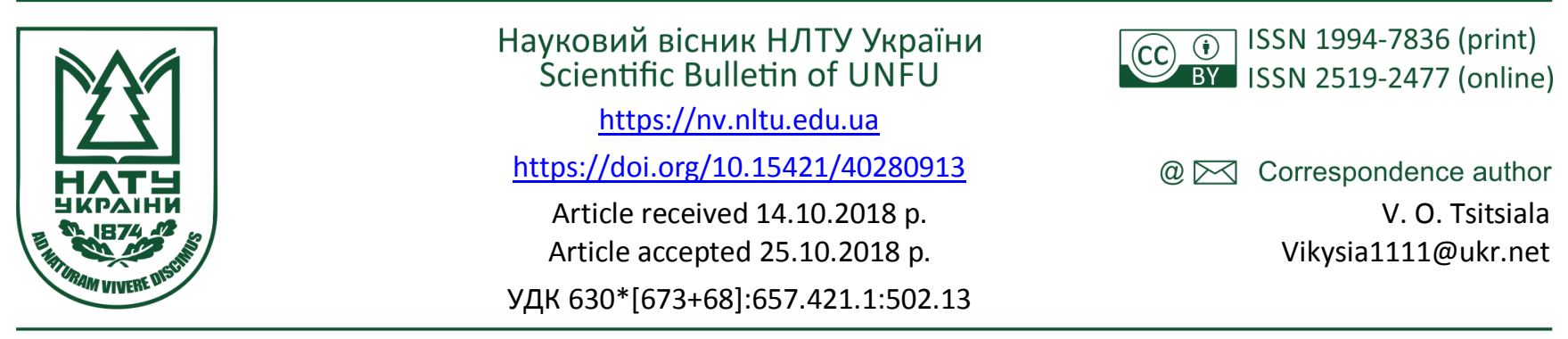

С. І. Лебедевич В. О. Цічяла

Національний лісотехнічний університет Украйни, м. Львів, Україна

\title{
АКТУАЛЬНІ ПРОБЛЕМИ ОРГАНІЗАЦІЇ ОБЛІКУ НЕОБОРОТНИХ АКТИВІВ ЕКОЛОГІЧНОГО СПРЯМУВАННЯ ЛІСОГОСПОДАРСЬКОГО ПІДПРИЄМСТВА
}

\begin{abstract}
У сучасних умовах виникає необхідність перегляду та уточнення принципів формування необоротних активів підприємства. Ресурси підприємства трансформуються в активи (відповідно - відображаються в балансі), лише після дотримання умов визнання, зокрема оцінки та ідентифікації, можна очікувати від них економічної вигоди (прибутку), це свідчить про актуальність і важливість цієї теми. Перше, на що потрібно звернути увагу, це організація первинного і зведеного обліку основних засобів екологічного призначення. Операцією, яка потребує окремих форм документів для іiї відображення в бухгалтерському обліку, є переоцінка основних засобів екологічного призначення, проблемним питанням обліку необоротних активів і О3 екологічного призначення $є$ облік екологічних витрат на їх поліпшення. Практична проблема, пов'язана 3 оцінкою необоротних активів, часто виникає під час проведення їх інвентаризації та виявлення таких, що не відображені на балансі підприємства. Розглянуто актуальні проблеми організації обліку необоротних активів екологічного спрямування лісогосподарського підприємства. Для цілей переоцінки потрібно поділити групи основних засобів екологічного призначення (враховуючи специфіку діяльності) на певні підгрупи, щоб зробити їх однорідними. Для покращення організації обліку запропоновано деталізований план рахунків необоротних активів екологічного призначення, з урахуванням діяльності лісового підприємства. Розроблено прикладні пропозиції вирішення проблем організації обліку необоротних активів екологічного спрямування лісогосподарського підприємства, які допоможуть підприємству чітко організувати облік необоротних активів, спрямованих на екологічну політику лісогосподарства. Основою управління $є$ інформація про екологічні витрати, отримана шляхом дослідження необоротних активів екологічного призначення діяльності підприємства, побудови механізму раціональної організації та методики обліку необоротних активів.
\end{abstract}

Ключові слова: необоротні активи; екологічне призначення; переоцінка; лісогосподарське підприємство; екоменеджмент; план рахунків.

Вступ. Питання теоретико-методологічних і практичних аспектів щодо організації обліку необоротних активів на сьогодні $є$ досить актуальні. Тому їх порушують у своїх роботах вітчизняні науковці, зокрема $\Phi$. Ф. Бутинець, Б. І. Валуєв, В. М. Жук, Г. Г. Кірейцев, М. В. Кужельний (Mochernyy, et al., 2010), С. І. Лебедевич (Lebedevych, Klym \& Khomyk, 2014), М. Ф. Огійчук та ін. Проте питання організації обліку необоротних активів лісогосподарських підприємств та їх оцінки потребують додаткового вивчення.

Предметом дослідження є організація обліку необоротних активів екологічного спрямування лісогосподарського підприємства.

Основними завданнями $€$ :

1) аналізування наявних проблем з організації обліку необоротних активів екологічного спрямування на лісогосподарських підприємствах;

2) розроблення пропозицій з організації обліку необоротних активів екологічного спрямування на лісогосподарських підприємствах.

Викладення матеріалу дослідження. У сучасних умовах, коли триває процес глобалізації економіки, виникає необхідність перегляду та уточнення принципів

формування необоротних активів підприємства. Адже доведено, що збільшення обсягів виробництва та реалізації конкурентоспроможної продукції на вітчизняному та світовому ринках дедалі більше потребують використання науково-технологічних знань, різних видів інновацій (Nematerialni aktyvy, 2005).

Так, активи - це сукупність майна, грошових коштів, об̆'єктів інтелектуальної власності конкретного суб'єкта господарювання, від використання яких упродовж певного періоду очікується отримання вигод (зазвичай, прибутку), а ресурси - це по-суті складники виробничого потенціалу підприємства, що використовують для досягнення поставлених цілей (Mochernyy, et al., 2010).

Перше, на що потрібно звернути увагу, це організація первинного і зведеного обліку основних засобів екологічного призначення. У типових формах документів не заповнюють усі колонки до заповнення, тому недоцільно використовувати ці форми. Це такі реквізити: норми амортизації основних засобів на капітальний ремонт, повне відновлення поняття балансової вартості та ін. Потрібно запроваджувати на підприємствах удосконалені форми первинних і зведених документів з обліку

Інформація про авторів:

Лебедевич Світлана Іванівна, д-р екон. наук, професор, кафедра обліку і аудиту. Email: lebedevych.sv@gmail.com Ціцяла Вікторія Орестівна, магістрант, кафедра обліку і аудиту. Email: Vikysia1111@ukr.net

Цитування за ДСту: Лебедевич С. І. Ціцяла В. О. Актуальні проблеми організації обліку необоротних активів екологічного спрямування лісогосподарського підприємства. Науковий вісник НлтУ України. Серія Економічна. 2018, т. 28, № 9. С. 65-67

Citation APA: Lebedevich, S. I., \& Tsitsiala, V. O. (2018). Actual problems of an accounting organization for enviromantally oriented indirect assets of forestry enterprise. Scientific Bulletin of UNFU, 28(9), 65-67. https://doi.org/10.15421/40280913

Науковий вісник НЛТУ України, 2018, т. 28, № 9 Scientific Bulletin of UNFU, 2018, vol. 28, no 9 
основних засобів, придбаних для їх екологічного спрямування, розробити нову форму Відомостей обліку зносу (амортизації) основних засобів, при цьому ввести додаткові показники, а саме: строк корисного використання основних засобів; справедлива вартість (у передбачених П(С)БО 7 випадках); дата та сума дооцінки або уцінки об'єктів; метод нарахування амортизації; ліквідаційна вартість; сума ПДВ, сплачена у зв'язку із надходженням об'єкта. Актуальним є проведення переоцінки основних засобів екологічного призначення, що $є$ складним і багаторівневим процесом. Складність цього процесу полягає в тому, що він потребує досить трудомістких розрахунків на усіх етапах його здійснення: від обгрунтованості прийняття рішення про проведення переоцінки до визначення іiі кінцевих результатів. Для визначення потреб у проведенні переоцінки основних засобів екологічного призначення відповідно до вимог П(С)БО 7 згідно 3 поглядами вчених запропонували форму "Акт оцінки справедливої вартості основних засобів" (Osnovni zasoby, 2006). Вона призначена для документального підтвердження справедливої вартості об'єктів основних засобів та обгрунтованості рішення про проведення їх переоцінки, яке вважають доцільною i доречною. За наявності усіх даних лісогосподарські підприємства повинні розраховувати справедливу вартість за допомогою інформаційних програм. Автоматизація розрахунку дає змогу оцінити необхідність проведення переоцінки щодо окремих об'єктів основних засобів. Для розрахунку індексу переоцінки, а також для обліку іï результатів загалом пропонують розроблений регістр аналітичного обліку - "Відомість обліку результатів переоцінки основних засобів".

Для трансформації бухгалтерського і податкового обліку екологічних витрат на покращення основних засобів запропоновано ввести в чинний План рахунків бухгалтерського обліку субрахунок 156 "Витрати на поточний ремонт основних засобів". За дебетом цього рахунку обліковувати витрати на ремонти, модернізацію, реконструкцію основних засобів, які виконані як господарськими, так і підрядними засобами, а за кредитом рахунку - їх списання згідно з чинними нормативними документами та облікової політики підприємства, субрахунок 157 "Витрати на капітальний ремонт основних засобів", сума капітального ремонту призведе до збільшення залишкової вартості О3, залишаючи незмінним термін експлуатації. Під час складання облікової політики потрібно чітко визначити способи ведення бухгалтерського обліку - первинного спостереження вартісного виміру, поточного групування та узагальнення фактів господарського життя. Важливо під час розроблення облікової політики знайти оптимальний спосіб ведення обліку на підприємстві, щоб він не спричинив плутанини та труднощів для бухгалтерів та водночас надавав вичерпну інформацію користувачам. Для переоцінки потрібно поділити групи О3 екологічного призначення (враховуючи специфіку діяльності) на певні підгрупи, щоб зробити їх однорідними. Наприклад, розподіл на необоротні активи природоохоронного призначення, рекреаційного призначення, оздоровчого призначення, щодо моніторингу довкілля для кожного синтетичного рахунку (Lebedevych, Klym \& Khomyk, 2014). Адже, під час переоцінки об'єкта основних засобів потрібно робити переоцінку усієї групи, до якої він належить. Це стосується таких груп, як "машини та обладнання" та "бу- динки, споруди та передавальні пристрої". А результати переоцінки потрібно оформлювати у відомості аналітичного обліку переоцінки основних засобів екологічного призначення. Отже, ця інформація буде використовувати для складання звітності та надаватиме користувачам вичерпні дані про переоцінку основних засобів екологічного призначення. Для дотримання принципу відповідності витрат і доходів, а отже, більш точного визначення фінансового результату запропоновано: витрати на відновлення основних засобів екологічного призначення, розмір яких не $\epsilon$ істотним для підприємства, відображати в періоді їх виникнення; екологічні витрати, що перевищують критерій істотності, рівномірно розподіляти між суміжними звітними періодами. Періодом розподілу витрат на виконання відбудовних робіт, що мають плановий характер, варто вважати очікуваний міжремонтний період. Собівартість позапланових робіт потрібно розподіляти протягом терміну корисного використання, що залишився.

В основу для визначення достовірної оцінки необоротного активу може бути покладено витратний підхід, який грунтується на визначенні вартості витрат, потрібних для відтворення або заміщення об'єкта оцінки (Natsionalnyy standart, 2007). Особливо актуальності набуватиме цей метод у разі відсутності основних первинних документів для взяття на облік необоротних активів (господарських договорів (угод) на їх придбання. На сьогодні проблемою багатьох лісових господарств є використання застарілої техніки, строк корисного використання яких давно вийшов. Це призводить до не тільки економічних втрат, але й екологічних, оскільки такі застарілі основні засоби здійснюють більші викиди шкідливих речовин, ніж модернізовані. I знову виникає практичне питання, наскільки об'єктивно можливо визначити такі втрати і як відобразити це документально.

Висновки. Узагальнюючи, варто зазначити, що неузгодженості в питаннях організації обліку та оцінки необоротних активів екологічного призначення мають значний вплив на достовірність інформації про загальний стан активів, що оприлюднюють суб'єкти господарювання. Лісогосподарським підприємствам потрібно звертати увагу на правильне розроблення облікової політики, яку покладено за основу первинного і зведеного обліку необоротних активів. Дедалі відчутніший вплив на теорію та практику бухгалтерського обліку загалом i необоротних активів зокрема, має його трансформація до міжнародних стандартів. Безсумнівним є необхідність орієнтуватись у цих питаннях на набутому вітчизняному досвіді, а також максимально наблизити теоретичні надбання до діючої практики.

\section{Перелік використаних джерел}

Lebedevych, S. I., Klym, N. M., \& Khomyk, Kh. R. (2014). Oblikovo-audytorske zabezpechennia lisohospodarskykh pidpryiemstv dlia staloho rozvytku Ukrainy. Lviv: Liha-Pres, 268 p. [In Ukrainian].

Mochernyy, S. V. (Ed.), et al. (2010). Ekonomichna entsyklopediya. (Vol. 1). Kyiv: Akademiya, 864 p. [In Ukrainian].

Natsionalnyy standart. (2007). Otsinka maynovykh prav intelektualnoyi vlasnosti. Postanova Kabinetu Ministriv Ukrayiny vid 3 zhovtnya 2007 r., № 1185. Oblik i finansy APK, 8-10. [In Ukrainian].

Nematerialni aktyvy. (2005). Polozhennya (standart) bukhhalterskoho obliku 8. Bukhhalteriya, 29(652), 48-51. [In Ukrainian].

Osnovni zasoby. (2006). Polozhennya (standart) bukhhalters'koho obliku 7. Zatverdzheno nakazom MFU vid 27.04.2000 r. № 92 z zminamy i dopovnennyamy vid 11.12.2006 r., № 1176. [In Ukrainian]. 


\section{АКТУАЛЬНЫЕ ПРОБЛЕМЫ ОРГАНИЗАЦИИ УЧЕТА НЕОБОРОТНЫХ АКТИВОВ ЭКОЛОГИЧЕСКОГО НАПРАВЛЕНИЯ ЛЕСОХОЗЯЙСТВЕННОГО ПРЕДПРИЯТИЯ}

В современных условиях возникает необходимость пересмотра и уточнения принципов формирования необоротных активов предприятия. Ресурсы предприятия трансформируются в активы (соответственно - находят отражение в балансе), только после соблюдения условий признания, в частности оценки и идентификации, можно ожидать от них экономической выгоды (прибыли), это свидетельствует об актуальности и важности данной темы. Первое, на что нужно обратить внимание, это организация первичного и сводного учета основных средств экологического назначения. Операцией, требующей отдельных форм документов для ее отражения в бухгалтерском учете, является переоценка основных средств экологического назначения, проблемным вопросом учета необоротных активов и ОС экологического назначения является учет экологических затрат на их улучшение. Практическая проблема, связанная с оценкой необоротных активов, в частности нематериальных, часто возникает во время проведения их инвентаризации и выявления таких, которые не отражены на балансе предприятия. Рассмотрены актуальные проблемы организации учета необоротных активов экологического направления лесохозяйственного предприятия. С целью улучшения организации учета предложено детализированный план счетов необоротных активов экологического назначения, с учетом деятельности лесного предприятия. Разработаны прикладные предложения решения проблем организации учета необоротных активов экологического направления лесохозяйственного предприятия, которые помогут предприятию четко организовать учет необоротных активов, направленных на экологическую политику лесохозяйственного предприятия. Основой управления является информация об экологических расходах, полученная путем исследования необоротных активов экологического назначения деятельности предприятия, построения механизма рациональной организации и методики учета основных средств.

Ключевые слова: необоротные активы; экологическое назначения; переоценка; лесохозяйственное предприятие; экоменеджмент; план счетов.

S. I. Lebedevich, V. O. Tsitsiala

Ukrainian National Forestry University, Lviv, Ukraine

\section{ACTUAL PROBLEMS OF AN ACCOUNTING ORGANIZATION FOR ENVIROMANTALLY ORIENTED INDIRECT ASSETS OF FORESTRY ENTERPRISE}

In modern conditions, there is a need to revise and clarify the principles of forming noncurrent assets of the enterprise. The resources of the enterprise are transformed into assets (correspondingly, they are reflected in the balance sheet) only after observance of the terms of recognition such as estimation, identification. We can expect their economic output (profit) that indicates the relevance and importance of this topic. The first thing to pay attention to is the organization of primary and consolidated accounting of basic means of the environmental purpose. An operation that requires separate forms of documents for its reflection in accounting is a reassessment of the main means of environmental purpose, problematic issues of accounting for noncurrent assets and environmental OZ is the accounting of environmental costs for their improvement. A practical problem associated with the valuation of non-current assets, intangible, in particular, often occurs when they inventory and identify those that are not reflected in the company's balance sheet. The paper deals with the actual problems of the organization of accounting for noncurrent assets of the ecological direction of the forestry enterprise. To reassess, it is necessary to divide the groups of main means of environmental purpose (taking into account the specifics of the activity) into certain subgroups in order to make them homogeneous. In order to improve forming of accounting, a detailed plan of accounts of noncurrent assets of ecological purpose was proposed, considering the activity of the forestry enterprise. Applied suggestions for solving the problems of organizing the accounting of noncurrent assets of the ecological direction of the forestry enterprise are developed, which will help the enterprise to clearly arrange the accounting of noncurrent assets aimed at the ecological policy of forestry. The basis of management is the information on environmental costs, obtained through the study of noncurrent assets of the environmental purpose of the enterprise, the construction of a mechanism for rational organization and methods of accounting for noncurrent assets.

Keywords: noncurrent assets; ecological purpose; reassessment; forestry enterprise; ecological management; account plan. 